\title{
Mechanical Properties and Grindability of Dental Cast Ti-Nb Alloys
}

\author{
Masafumi KIKUCHI, Masatoshi TAKAHASHI and Osamu OKUNO \\ Division of Dental Biomaterials, \\ Graduate School of Dentistry, Tohoku University \\ 4-1, Seiryo-machi, Aoba-ku, Sendai, Miyagi, 980-8575 Japan
}

Received April 11, 2003/Accepted June 26, 2003

\begin{abstract}
Aiming at developing a dental titanium alloy with better mechanical properties and machinability than unalloyed titanium, a series of $\mathrm{Ti}-\mathrm{Nb}$ alloys with $\mathrm{Nb}$ concentrations up to $30 \%$ was made. They were cast into magnesia-based molds using a dental casting machine and the mechanical properties and grindability of the castings were examined. The hardness of the alloys with $\mathrm{Nb}$ concentrations of $5 \%$ and above was significantly higher than that of titanium. The yield strength and tensile strength of the alloys with $\mathrm{Nb}$ concentrations of $10 \%$ and above were significantly higher than those of titanium, while the elongation was significantly lower. A small addition of niobium to titanium did not contribute to improving the grindability of titanium. The Ti- $30 \% \mathrm{Nb}$ alloy exhibited significantly better grindability at low grinding speed with higher hardness, strength, and Young's modulus than titanium, presumably due to precipitation of the $\omega$ phase in the $\beta$ matrix.
\end{abstract}

Key words: Titanium alloy, Mechanical property, Grindability

\section{INTRODUCTION}

Titanium is well known as a dental material for its excellent biocompatibility and corrosion resistance. Another advantage is that the ore is more plentiful than other precious metals used for conventional dental alloys. However, a considerable amount of research and development was necessary to overcome difficulties related to the processing of titanium, which are caused by its high melting point and high reactivity at high temperature. Titanium is now practical for use in dentistry, especially for casting $^{1-4)}$.

In general, it is desirable that a single stable metal be used for dental prostheses in the oral cavity from the point of view of safety, but the properties of unalloyed titanium are not suitable for all purposes. The properties of titanium can be changed when the material is alloyed with other elements ${ }^{5-7)}$. Some titanium alloys are known for their unique characteristics as a metal: the super elasticity and shapememory effect of the Ti-Ni alloy or the super plasticity of the Ti-6Al-4V alloy, for example. The former is utilized in dentistry for orthodontic wires ${ }^{8)}$, and the latter, for super plastic forming of denture bases ${ }^{9}$. Many other titanium alloys for dental use have been developed, and their properties have been studied ${ }^{10-18)}$, mainly to improve the strength and castability of pure titanium. However, few dental titanium alloys have been considered through machining (cutting or grinding), a process that is accomplished by the recently developed dental CAD/CAM systems. 
It is a concern that the corrosion resistance or biocompatibility of titanium will decrease by alloying it. In this respect, niobium is a good candidate as an alloying element $^{19-25)}$. Industrial $\mathrm{Ti}-45$ mass $\% \mathrm{Nb}$ (hereafter "mass\%" will be referred to as “\%”) alloy is developed as a corrosion-resistant titanium alloy ${ }^{26,27)}$. Some Ti-Nb alloys are known as super-conducting alloys ${ }^{19)}$. In dentistry, Ti-Nb binary alloys have been examined principally for dental implant applications. Breme and Wadewitz investigated the corrosion resistance of $\mathrm{Ti}-40 \% \mathrm{Nb}$ and $\mathrm{Ti}-50 \% \mathrm{Nb}$ in $0.9 \%$ saline solution and found that it was no worse than commercially pure (CP) titanium ${ }^{28)}$. Hildebrand et al. reported that the electrochemical behavior in artificial saliva of the $\mathrm{Ti}-30 \% \mathrm{Nb}$ alloy is similar to that of $\mathrm{CP}$ titanium $^{29)}$. Lee et al. examined the corrosion behavior of a series of binary $\mathrm{Ti}-\mathrm{Nb}$ alloys with $\mathrm{Nb}$ contents up to $35 \%{ }^{30}$. All the Ti-Nb alloys turned out to have excellent corrosion resistance in Hank's solution. Floquet et al. studied the biological response of the $\mathrm{Ti}-30 \% \mathrm{Nb}$ alloy ${ }^{31}$. Their experiments revealed that the $\mathrm{Ti}-30 \% \mathrm{Nb}$ alloy possesses excellent cytocompatibility, as does $\mathrm{CP}$ titanium. These studies suggested that the Ti-Nb alloy has a potential as a dental alloy with sufficient corrosion resistance and biocompatibility.

In previous studies, the mechanical properties and grindability of titanium alloyed with silver $(5,10$, and $20 \% \mathrm{Ag})$ or copper $(2,5$, and $10 \% \mathrm{Cu})$ were examined $^{18,32)}$. As the concentration of silver or copper in the alloys increased, the strength and hardness became higher, and the elongation became lower than those of titanium $^{18)}$. Changes in the mechanical properties by alloying were probably caused by solid-solution strengthening of the $\alpha$ phases and by precipitation of the intermetallic compounds $\left(\mathrm{Ti}_{2} \mathrm{Ag}\right.$ or $\left.\mathrm{Ti}_{2} \mathrm{Cu}\right)$. Furthermore, the grindability of titanium was improved through alloying, particularly at a high grinding speed ${ }^{32)}$. It is probable that a decrease in the elongation was the primary contributor to the grindability of the alloys.

Although no titanium-niobium intermetallic compound is formed according to the equilibrium phase diagram for the binary titanium-niobium alloy ${ }^{33,34)}$, it is known that the martensitic transformation from the $\beta$ to the $\alpha$ phase of the alloy is sluggish, allowing many metastable transformations to occur ${ }^{34,35)}$. It was reported that the mechanical properties of the alloy vary according to the concentration of niobium ${ }^{28,30,36}$. Accordingly, there is a possibility that a certain $\mathrm{Ti}-\mathrm{Nb}$ alloy has better grindability than titanium. In this study, a series of binary $\mathrm{Ti}-\mathrm{Nb}$ alloys with $\mathrm{Nb}$ concentrations up to $30 \%$ was made. The mechanical properties and grindability of their castings were evaluated in the hope of developing a titanium alloy for dental prostheses that has better mechanical properties and machinability than unalloyed titanium.

\section{MATERIALS AND METHODS}

\section{Preparation of ingots}

The Ti-Nb system is classified as a system with continuous $\beta$ solubility and partial miscibility in the $\alpha$ phase $^{6)}$. According to the equilibrium phase diagram, the alloy with a niobium concentration up to $4 \%$ is located within the $\alpha$ region at $400^{\circ} \mathrm{C}$. 
From $4 \%$ to $56 \%$, the alloy is located within the $\alpha+\beta$ region $^{33,34)}$. In the present study, Ti-Nb alloys with niobium concentrations of $2,5,10,15,20,25$, and $30 \%$ were examined.

Buttons (15 $\mathrm{g}$ each) of titanium and Ti-Nb alloys corresponding to the desired concentrations were made by melting titanium ( $>99.8 \%$, grade S-90, Sumitomo Sitix, Amagasaki, Japan) and niobium ( $>99.9 \%$, H. C. Starck, Goslar, Germany) in an argon- arc melting furnace (TAM-4S, Tachibana-Riko, Sendai, Japan). After the chamber was evacuated to $5 \mathrm{mPa}$, high-purity (>99.9999\%) argon gas (Nipponsanso, Kawasaki, Japan) was introduced until the pressure reached $50 \mathrm{kPa}$ for the melting atmosphere. To minimize gas absorption, titanium getter was melted before melting the buttons. A batch of buttons was melted six times in total; they were inverted five times to ensure homogeneity.

\section{Preparation of specimens}

To make the specimens by casting, two types of patterns were invested into a magnesia mold (Selevest CB, Selec, Osaka, Japan). Four tests (phase identification, hardness, measurement of Young's modulus, and grinding) were conducted using a wax pattern $(3.5 \mathrm{~mm} \times 8.5 \mathrm{~mm} \times 30.5 \mathrm{~mm})$. For a tensile test, a pattern of $3.0 \mathrm{~mm}$ in diameter and $15 \mathrm{~mm}$ in gauge length was used. According to the manufacturer's instructions, the mold was heated to $850^{\circ} \mathrm{C}$ at $6^{\circ} \mathrm{C} \cdot \mathrm{min}^{-1}$ with a one-hour hold period, followed by cooling to $200^{\circ} \mathrm{C}$ in a computerized furnace (KDF-009G, Denken, Kyoto, Japan). Each metal button was arc-melted and cast into the mold using a dental casting machine (CASTMATIC-S, Iwatani, Osaka, Japan). After casting, the molds were kept at room temperature. Prior to the tests, $250 \mu \mathrm{m}$ from all the surfaces of the cast slabs was ground to remove the hardened surface layer ${ }^{37,38)}$, producing specimens measuring $3.0 \mathrm{~mm} \times 8.0 \mathrm{~mm} \times 30 \mathrm{~mm}$.

\section{Phase identification}

X-ray diffractometry for the alloys was performed on an X-ray diffraction system (XRD) (X'Pert-MPD PW3050, Philips, Amsterdam, Netherlands) with a scan rate of 0.05 degree $\cdot \mathrm{s}^{-1}$ using $\mathrm{Cu}-\mathrm{K} \alpha$ radiation $(40 \mathrm{kV}, 45 \mathrm{~mA})$. The peaks were identified according to the JCPDS file (1998) and a study conducted by Moffat and Kattner $(1988)^{35)}$.

\section{Microhardness test}

Vickers hardness was evaluated for a polished cross-section of each specimen using a microhardness tester (HM-102, Akashi, Yokohama, Japan) with a $1.961 \mathrm{~N}$ load and $30 \mathrm{~s}$ dwell time. Three specimens were used to measure the hardness for each metal. The measurements were made at three randomly chosen locations in each specimen. The results were analyzed using one-way ANOVA and Scheffé's test at $\alpha=0.05$.

\section{Tensile test}

Tensile testing of each specimen was conducted at room temperature at a crosshead 
speed of $0.5 \mathrm{~mm} \cdot \mathrm{min}^{-1}$ on a universal testing machine (DSS-2000, Shimadzu, Kyoto, Japan). Six specimens for each metal were used to determine the $0.2 \%$ offset yield strength, ultimate tensile strength, and elongation to failure. The results were analyzed using one-way ANOVA and Scheffé's test at $\alpha=0.05$. The fractured surfaces were observed using an electron probe microanalyzer (EPMA) (JXA-8900R, JEOL, Tokyo, Japan).

\section{Measurement of Young's modulus}

Young's modulus of the alloys was measured using an ultrasonic pulser/receiver (Model 5800, Panametrics, Waltham, MA) and transducers (V208 and V156, Panametrics). Three specimens were used for each metal. The results were analyzed using one-way ANOVA followed by Scheffé's test at $\alpha=0.05$.

\section{Grinding test}

An experimental grindability tester equipped with an electric dental handpiece for dental laboratory use (MICROMOTOR LM-I, GC, Tokyo, Japan) was made based on the testing apparatus shown in JIS T5209 "Dental carborundum wheels." 32,39) Carborundum wheels (\#4, Shofu, Kyoto, Japan) were used as grinding tools. The diameter of each wheel was measured before and after grinding. A thinner crosssection $(3.0 \mathrm{~mm})$ of the specimens was ground at one of the five circumferential speeds $500,750,1000,1250$, or $1500 \mathrm{~m} \cdot \mathrm{min}^{-1}$ at $0.98 \mathrm{~N}$. The specimen and a wheel were covered during grinding, and metal chips were collected in a glass beaker.

Grindability was evaluated by the volume of metal removed per minute (grinding rate) and the volume ratio of metal removed compared with the wheel material lost, which was calculated from the diameter loss (grinding ratio) ${ }^{32}$. The volume of metal removed by one minute of grinding was calculated from the density, previously measured using Archimedes' principle, and the weight loss of the specimen. Three specimens were used to evaluate the grindability of each metal. The test was performed twice for every grinding speed. A new wheel was applied for every test. The results were analyzed using one-way ANOVA and Scheffé's test at $\alpha=0.05$. The ground surfaces of the metals, metal chips, and surfaces of the wheels were examined using the EPMA.

\section{RESULTS}

\section{Phase identification}

The XRD patterns of the titanium and the Ti-Nb alloys are shown in Fig. 1. Peaks corresponding to the $\alpha$ and/or metastable $\alpha^{\prime}$ phase (both hcp) were found in the Ti$\mathrm{Nb}$ alloy with a niobium concentration up to $10 \%$. In the $\mathrm{Ti}-15 \% \mathrm{Nb}$, a small peak presumably corresponding to the metastable $\alpha^{\prime \prime}$ phase (orthorhombic) appeared. The broad peaks found in the $\mathrm{Ti}-20 \% \mathrm{Nb}$ and $\mathrm{Ti}-25 \% \mathrm{Nb}$ appeared to be primarily comprised of the metastable $\alpha^{\prime \prime}$ phase. In the Ti-30\% Nb, peaks corresponding to the $\omega$ phase (hexagonal) and the metastable $\beta$ (bcc) phase were found. 

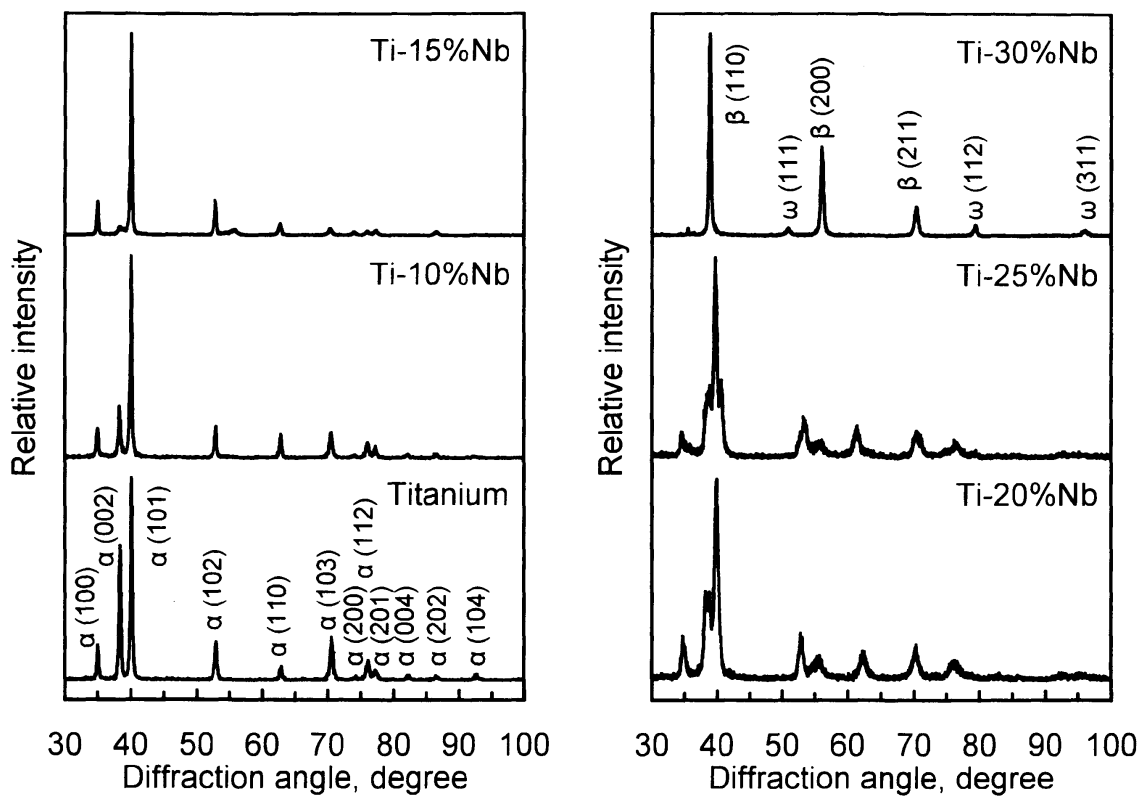

Fig. 1 X-ray diffraction patterns of the Ti-Nb alloys.

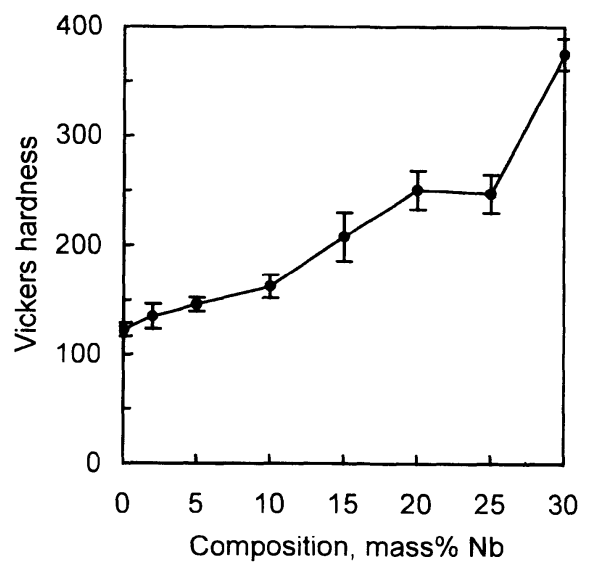

Fig. 2 Hardness of the Ti-Nb alloys. Error bar: \pm S.D.

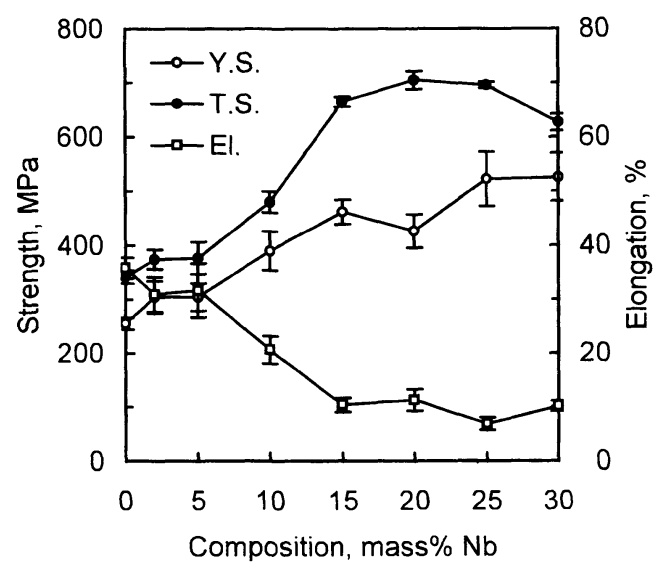

Fig. 3 Yield strength, tensile strength, and elongation of the $\mathrm{Ti}-\mathrm{Nb}$ alloys. Error bar: \pm S.D.

\section{Microhardness}

The Vickers hardness of the Ti-Nb alloys with $\mathrm{Nb}$ concentrations of $5 \%$ and above was significantly higher $(p<0.01)$ than that of titanium (Fig. 2). The hardness of the $\mathrm{Ti}-20 \% \mathrm{Nb}$ and $\mathrm{Ti}-25 \% \mathrm{Nb}$ was almost the same. Ti-30\% $\mathrm{Nb}$ exhibited the highest hardness value of the metals tested. 
Yield strength, tensile strength, and elongation

The values of the yield strength, tensile strength, and elongation to failure for each alloy tested are summarized in Fig. 3. The yield strength of the Ti-Nb alloys with niobium concentrations of $10 \%$ and above was significantly higher $(p<0.001)$ than that of titanium. The value for Ti-30\% Nb was about $530 \mathrm{MPa}$, which was more than twice that for titanium.

The tensile strength of the Ti-Nb alloys with niobium concentrations of $10 \%$ and above was significantly higher $(p<0.001)$ than that of titanium. The tensile strength increased as the concentrations of niobium increased until $20 \%$. The tensile strength of $\mathrm{Ti}-20 \% \mathrm{Nb}$ and $\mathrm{Ti}-25 \% \mathrm{Nb}$ was about $700 \mathrm{MPa}$, more than twice that of titanium. The tensile strength for the Ti-30\% $\mathrm{Nb}$ was greater than $600 \mathrm{MPa}$.

Titanium exhibited the highest elongation of $36 \%$. The elongation of the Ti-Nb alloys with niobium concentrations of $10 \%$ and above was significantly lower ( $p$ $<0.001$ ) than that of titanium. However, there was no significant difference in elongation among the Ti-Nb alloys with niobium concentrations of $15 \%$ and above. The elongation for $\mathrm{Ti}-30 \% \mathrm{Nb}$ was about $10 \%$. Transverse cracks were observed on the side of the tensile specimens. The cracks in the titanium and the Ti-Nb alloys with a lower concentration of niobium were more widely spread in the tensile direction compared with those of the alloys with a higher concentration. Dimples, which are a feature of a ductile fracture, were observed on the fractured surfaces of all the metals.

\section{Young's modulus}

Young's modulus decreased as the concentrations of niobium increased until $20 \%$ (Fig. 4). The value for the Ti-Nb alloys with $\mathrm{Nb}$ concentrations from $5 \%$ to $25 \%$ was significantly lower $(p<0.001)$ than that for the titanium, while that for the Ti$30 \% \mathrm{Nb}$ was significantly higher $(p<0.001)$. Among the metals tested, $\mathrm{Ti}-20 \% \mathrm{Nb}$ and

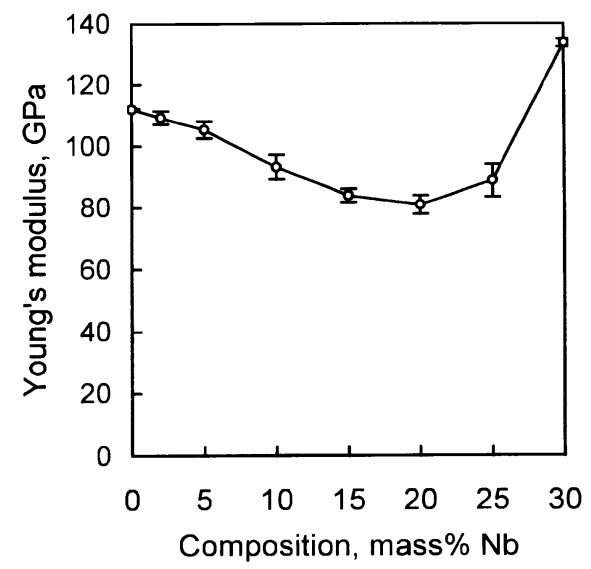

Fig. 4 Young's modulus of the Ti-Nb alloys. Error bar: \pm S.D. 
$\mathrm{Ti}-30 \% \mathrm{Nb}$ exhibited the lowest and the highest Young's modulus, respectively.

\section{Grinding test}

The grindabilities of the Ti-Nb alloys at five different grinding speeds are summarized in Fig. 5. For all the speeds, there was no significant difference in the grinding rate among the titanium and the $\mathrm{Ti}-\mathrm{Nb}$ alloys with a niobium concentration of $25 \%$ and below. At the grinding speed of 500 and $750 \mathrm{~m} \cdot \mathrm{min}^{-1}$, the rate for the $\mathrm{Ti}-30 \% \mathrm{Nb}$ was notably higher than that of the other metals tested $(p<0.001)$ and twice that of

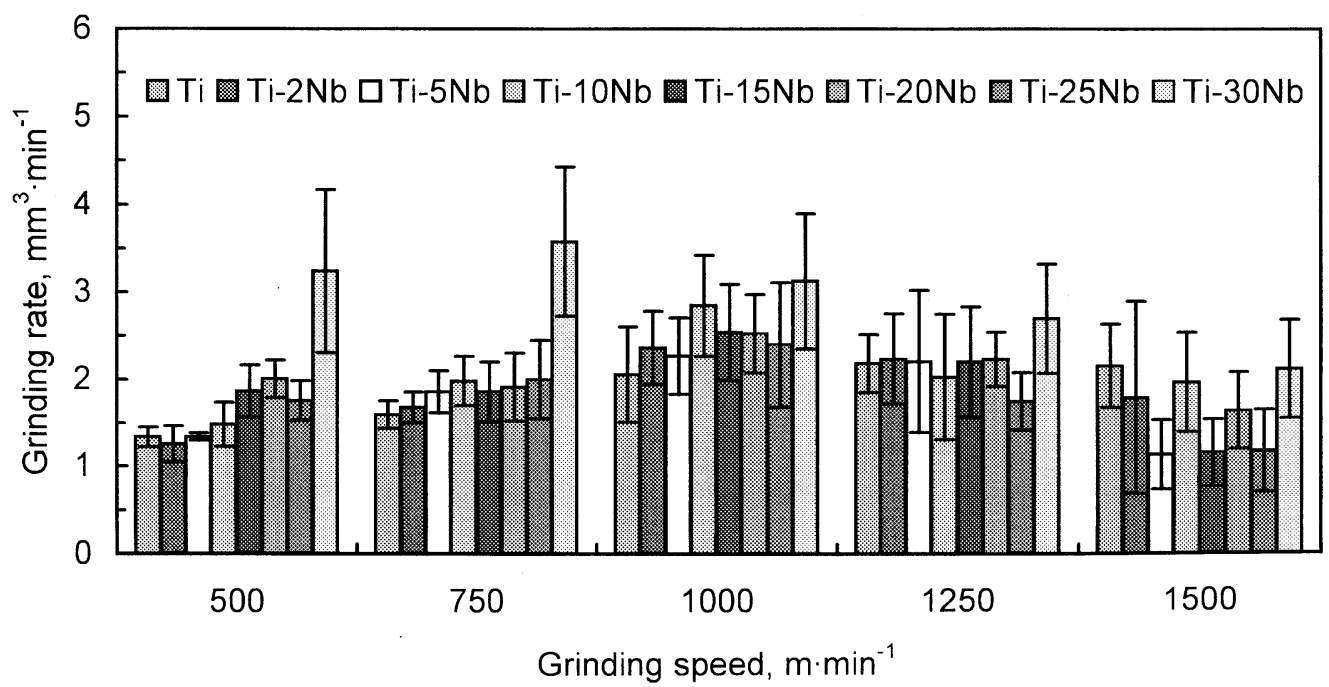

(a) Grinding rate

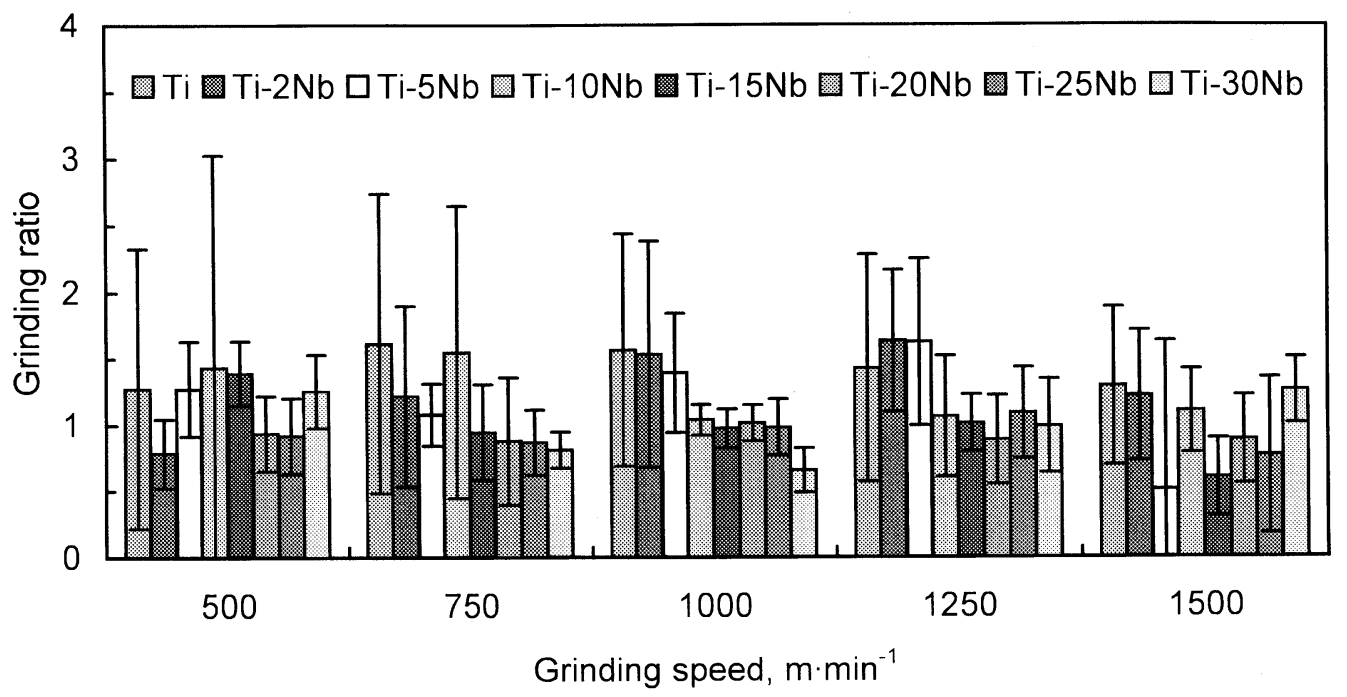

(b) Grinding ratio

Fig. 5 Grindability of the Ti-Nb alloys. Error bar: \pm S.D. 
titanium. However, at $1000 \mathrm{~m} \cdot \mathrm{min}^{-1}$ and above, the rate of the $\mathrm{Ti}-30 \% \mathrm{Nb}$ decreased, and the advantage over titanium was reduced. As for the grinding ratio, there was no significant difference among the metals for all speeds.

As shown in Fig. 6, there was no pronounced difference in the appearance of the ground surface between $\mathrm{Ti}-30 \% \mathrm{Nb}$, which exhibited significantly better grindability, and the other metals at $500 \mathrm{~m} \cdot \mathrm{min}^{-1}$. Sparking accompanied the grinding as the grinding speed increased. To a greater or lesser degree, grinding burns were ob-
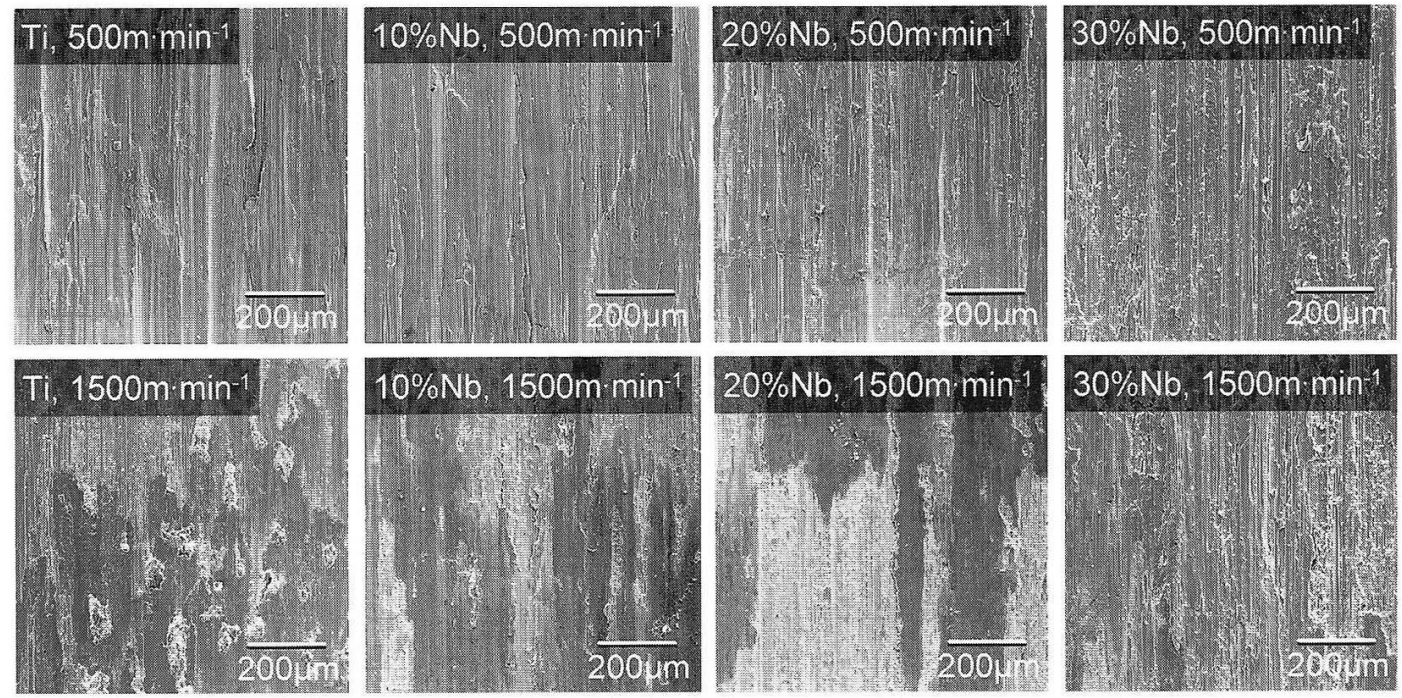

Fig. 6 Ground surfaces of the Ti-Nb alloys.
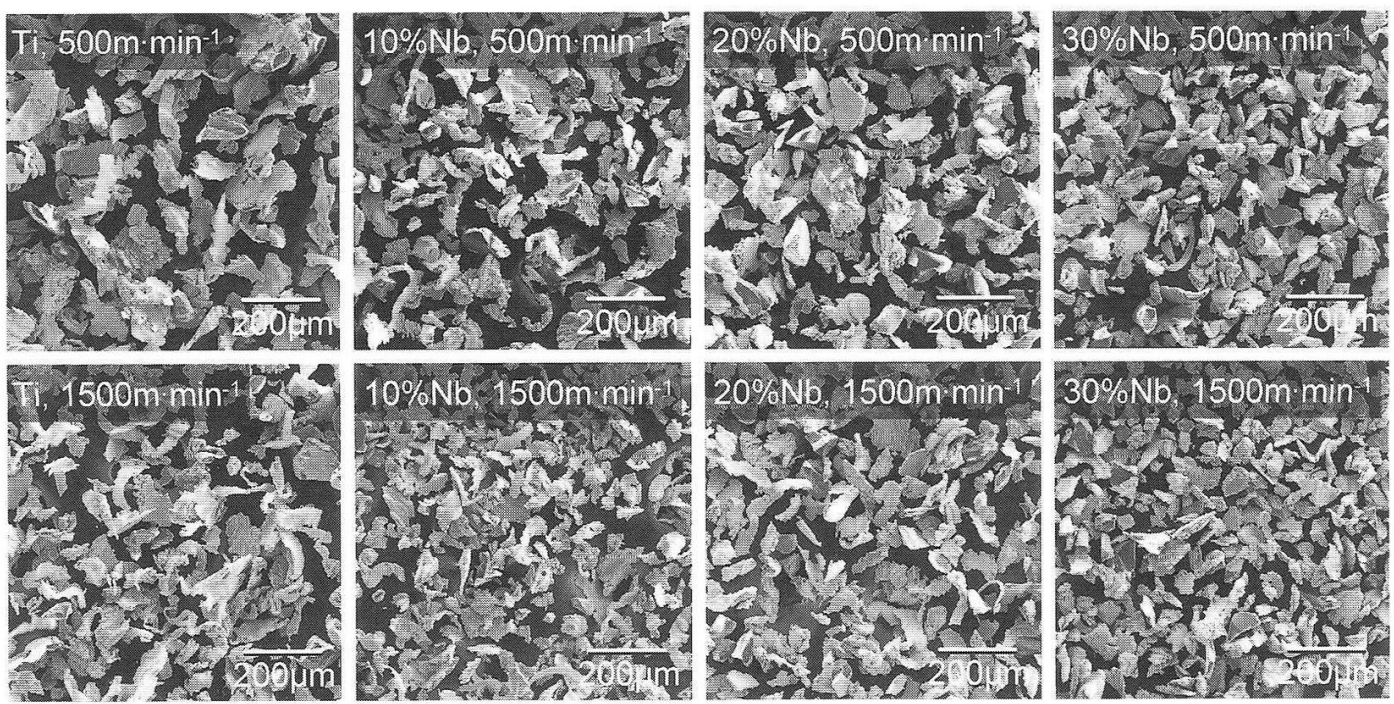

Fig. 7 Metal chips resulting from grinding. 

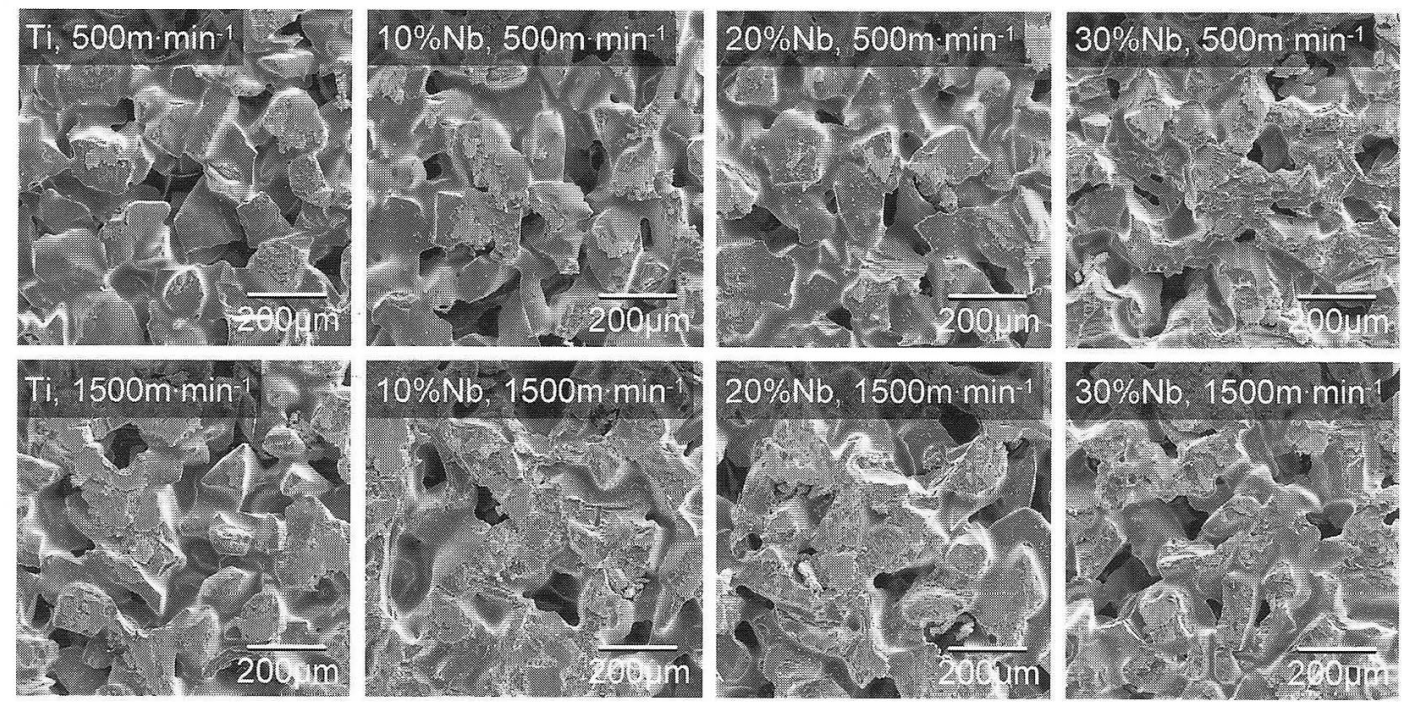

Fig. 8 Wheel surfaces after grinding.

served on the ground surfaces of most of the specimens when ground at high speed. Adhesion of metal was also observed on the ground surfaces, particularly on titanium. Typical metal chips that resulted from grinding at $500 \mathrm{~m} \cdot \mathrm{min}^{-1}$ and $1500 \mathrm{~m}$. $\min ^{-1}$ are shown in Fig. 7. Although no quantitative analysis was performed, the size of the metal chips of the $\mathrm{Ti}-\mathrm{Nb}$ alloys generally looked somewhat smaller than those of titanium. In titanium, there were a number of long chips. Wear of some abrasive particles embedded in the matrix of the wheel (dulling) or adhesion of metal on the wheel surface (loading) was found, especially at high speed (Fig. 8). However, there was no clear difference between the appearance of the titanium and the Ti-Nb alloys.

\section{DISCUSSION}

\section{Alloy phases}

The melting temperature of the $\mathrm{Ti}-\mathrm{Nb}$ alloy gradually increases as the concentration of niobium increases. The temperature of $\mathrm{Ti}-30 \% \mathrm{Nb}$ is estimated to be $1760^{\circ} \mathrm{C}$, while that of titanium and niobium are $1670^{\circ} \mathrm{C}$ and $2469^{\circ} \mathrm{C}$, respectively ${ }^{33)}$. Rapid allotropic transformation of pure titanium from the $\beta$ (bcc) to the $\alpha$ (hcp) phase occurs when it is cooled through approximately $882^{\circ} \mathrm{C}$ and no $\beta$ phase exists at room temperature. Alloying elements for titanium are classified as $\alpha$ or $\beta$ stabilizers $^{5,6)}$. Some $\beta$ stabilizers decrease the transformation temperature and the transformation speed, and have the potential to retain the metastable $\beta$ phase at room temperature by nonequilibrium solidification. Common metallic elements used for conventional dental gold alloys (namely $\mathrm{Au}, \mathrm{Ag}$, and $\mathrm{Cu}$ ) belong to the group of $\beta$ stabilizers. By alloying titanium with such elements, it is possible to lower the melting point and decrease the reactivity, which would facilitate casting. This is probably the main 
reason that a variety of metastable $\beta$-type titanium alloys have been studied for dental casting ${ }^{10-18}$.

Although niobium is a $\beta$ stabilizer, its ability to retain the $\beta$ phase $(\beta$-stabilizing power) is not so strong ${ }^{5)}$. In other words, the $\beta$ phase could not be retained with a small content of niobium. According to the Ti-Nb equilibrium phase diagram, experimental Ti-Nb alloys were expected to exhibit martensitic transformation from $\beta$ to $\alpha$ or $\alpha+\beta^{33,34)}$. In reality, the specimens were made by casting and departed from equilibrium. The martensitic transformation from the $\beta$ to the $\alpha$ phase of the alloy is slow, allowing various metastable phases, such as $\alpha^{\prime}, \alpha^{\prime \prime}$, and $\omega$, to form ${ }^{34,35)}$. Formation of the metastable phases is affected by the concentration of an additional element and heat treatment. The martensite start ( $\beta$ to $\alpha^{\prime}$ phase) temperature for Ti$17.5 \mathrm{~mol} \% \mathrm{Nb}(29.2 \% \mathrm{Nb})$ is about $300^{\circ} \mathrm{C}^{6,40)}$.

The $\omega$ phase was detected in the Ti-30\% Nb by XRD. The $\omega$ phase is a metastable phase, which precipitates in a titanium-transition metal alloy ${ }^{6)}$. It is known that the presence of the $\omega$ phase markedly affects the mechanical properties of the alloy ${ }^{41}$. There are two types of $\omega$ phases: athermal and isothermal ${ }^{6,42-44)}$. The former appears when the alloy is quenched form the $\beta$ phase. The particles are finely dispersed in the $\beta$ phase and too small to be detected optically ${ }^{6)}$. The compositional limits of the $\omega+\beta$ phase in the quenched Ti-Nb alloy are reported to be from $12 \mathrm{~mol} \%(20.9 \%)$ to $20 \mathrm{~mol} \%(32.7 \%)^{6}$. The latter is formed by prolonged aging at below about $400^{\circ} \mathrm{C}$. Considering the cooling speed after casting and the mechanical properties discussed later, it is suggested that the thermal history of the as-cast specimens is close to that of quenched rather than aged for a long time and the type of the $\omega$ phase in the $\mathrm{Ti}-30 \% \mathrm{Nb}$ is very likely athermal.

\section{Mechanical properties}

The hardness and strength of the $\mathrm{Ti}-\mathrm{Nb}$ alloys increased on the whole as the concentration of niobium increased. It is known that the presence of the $\alpha^{\prime}$ significantly increases the hardness of $\mathrm{Ti}-\mathrm{Nb}$ alloys ${ }^{45)}$. The stagnation of the increase in hardness around a niobium concentration from $20 \%$ to $25 \%$ is probably due to the formation of the $\alpha^{\prime \prime}$ phase, which is softer than the $\alpha^{\prime}$ phase ${ }^{45)}$. The high value of $\mathrm{Ti}-30 \% \mathrm{Nb}$ is caused by formation of the $\omega$ phase $^{41,45)}$. The increase in the strength and the decrease in the elongation of the $\mathrm{Ti}-\mathrm{Nb}$ alloy with a niobium concentration are ascribable to the same mechanism as the hardness ${ }^{30,36)}$. Although there was a small discrepancy in the niobium concentration, the change in the yield strength was basically similar to that in the hardness. The indentation hardness measurements are essentially a measure of the elastic limit of the material ${ }^{46)}$. The local minimum yield strength at $20 \% \mathrm{Nb}$ was probably caused by the formation the of the $\alpha^{\prime \prime}$ phase. The transverse cracks observed on the surface of the tensile specimens suggest that the hardened surfaces of the cast specimens, where the cracks initiated, are brittle. This does not mean that the specimens are brittle at the core because the cracks were widened in the tensile direction. The yield strength and elongation for the $\mathrm{Ti}-30 \% \mathrm{Nb}$ satisfied the minimum requirement for cobalt-based dental casting alloys (500 $\mathrm{MPa}$ 
and $3 \%$, respectively $)^{47)}$ and hardened Type 4 gold casting alloys (450 $\mathrm{MPa}$ and $3 \%$, respectively $)^{48)}$. Precaution is needed when considering aging of the $\mathrm{Ti}-\mathrm{Nb}$ alloy to control the mechanical properties because it is known that the formation of an isothermal $\omega$ phase in a $\beta$-type titanium alloy will cause a sharp loss of ductility in the alloy $^{6,41,49,50)}$.

The elastic modulus of titanium is strongly influenced by the alloying elements and heat treatment ${ }^{51,52)}$. The elastic modulus of the annealed Ti-Mo, Ti-V, and $\mathrm{Ti}-\mathrm{Nb}$ alloys monotonously decreases as the concentration of an alloying element increases $^{45,53)}$. On the other hand, when quenched from the $\beta$ phase, the modulus of the alloys at first decreases as the concentration of the alloying element increases. The modulus is then restored to the initial magnitude or even higher. The decrease in the modulus is due to the formation of $\alpha^{\prime}$ and $\alpha^{\prime \prime}$, and the subsequent increase in the value is due to the formation of the $\omega$ phase $^{45,53)}$. The modulus of the Ti-Nb alloy will again decrease when the single metastable $\beta$ phase is formed ${ }^{45)}$. The change in Young's modulus of the as-cast specimens in the present study was similar to that of the quenched ones in the previous study ${ }^{45)}$. Hence it is suggested that the high Young's modulus of the Ti- $30 \% \mathrm{Nb}$ in the present study was due to the formation of the $\omega$ phase. The higher value of $\mathrm{Ti}-30 \% \mathrm{Nb}$ than of titanium is favorable for prostheses that are subjected to high stress. It is also advantageous to machining, since the relatively low Young's modulus of titanium is one reason for its poor machinability ${ }^{54)}$.

Lee et al. studied the microstructure and mechanical properties of a series of binary $\mathrm{Ti}-\mathrm{Nb}$ alloys with $\mathrm{Nb}$ contents up to $35 \%{ }^{30)}$. It was reported that the metastable $\beta$ phase started to be retained when the $\mathrm{Nb}$ contents were increased to $25 \%$ or higher. With a niobium content of $30 \%$ or higher, the $\beta$ phase was almost entirely retained. Ti-27.5\% $\mathrm{Nb}$ exhibited the maximum hardness, bending strength, and bending modulus caused by precipitation of the $\omega$ phase. On the other hand, the $\omega$ phase and $\beta$ phase were not found until $30 \%$ in the present study. $\mathrm{Ti}-30 \% \mathrm{Nb}$ exhibited the maximum hardness, yield strength, and Young's modulus. The slight difference in the concentration of niobium between the two studies can be attributed to the difference in the casting conditions. Although the same type of casting machine was used, the alloys were cast into a room temperature graphite mold and cooling after casting was faster than in the present study. Their hardness values for the titanium and the $\mathrm{Ti}-\mathrm{Nb}$ alloys were in general higher than those in the present study. The most likely explanation is that the amount of oxygen in the ingots, which were prepared using the dental casting machine, was larger. The hardening effect of oxygen in titanium is very large $e^{5,55)}$.

\section{Grindability}

Unalloyed niobium is ductile and may be machined by the usual technique used for other ductile metals, but it has a tendency to gall ${ }^{56)}$. A small addition of niobium to titanium was ineffective for improving the grindability of titanium. The poor thermal conductivity of titanium is regarded as one reason that the material is difficult 
to machine. The low thermal conductivity of a material inhibits the dissipation of heat and causes high temperature at the cutting edges of a tool, which decreases tool life. The value for the Ti- $45 \% \mathrm{Nb}$ alloy is reported to be $10 \mathrm{~W} \cdot \mathrm{m}^{-1} \cdot \mathrm{K}^{-1}$, less than half that of titanium $\left(21.9 \mathrm{~W} \cdot \mathrm{m}^{-1} \cdot \mathrm{K}^{-1}\right)^{26,57)}$. It is conceivable that the thermal conductivity of titanium worsened by alloying with niobium in the present study. In addition, higher strength and hardness of a material generally make machining of the material more difficult ${ }^{58)}$. However, the $\mathrm{Ti}-30 \% \mathrm{Nb}$ alloy had a higher grinding rate than did titanium at low speed.

High ductility can be a reason of poor machinability of a material ${ }^{59,60)}$. Large deformation of a material during formation of chips brings about a high cutting temperature. For example, industrial free-cutting titanium and titanium alloys, which contain sulfur and rare-earth metals, have been developed ${ }^{61)}$. Improved metal chip breakability by the presence of small inclusions in the matrix is an explanation for their favorable machinability. It is noteworthy that there was no significant difference in elongation between the basic grades and the free-cutting grades ${ }^{61)}$. It seems that the reduction in bulk elongation is not always necessary for better machinability.

In a comparison with the $\mathrm{Ti}-\mathrm{Ag}$ and $\mathrm{Ti}-\mathrm{Cu}$ alloys ${ }^{18,32)}$, one possible explanation for the better grindability of the $\mathrm{Ti}-30 \% \mathrm{Nb}$ alloy is its reduced ductility. Unlike Ti$20 \% \mathrm{Ag}$ or $\mathrm{Ti}-10 \% \mathrm{Cu}, \mathrm{Ti}-30 \% \mathrm{Nb}$ had a less pronounced decrease in the size of the metal chips than titanium. From the point of view of reduced elongation, it is probable that the $15 \%, 20 \%$, and $25 \% \mathrm{Nb}$ alloys also have better grindability than titanium, as does the $30 \% \mathrm{Nb}$. However, there was no significant difference in the grinding rate among the $\mathrm{Ti}-\mathrm{Nb}$ alloys with niobium concentrations up to $25 \%$ and titanium. This signifies that the bulk elongation is not the only characteristic that dominates the grindability of this alloy. There were differences in the alloy phase and Young's modulus between $\mathrm{Ti}-30 \% \mathrm{Nb}$ and the other alloys tested. It is possible that the improved grindability of $\mathrm{Ti}-30 \% \mathrm{Nb}$ is attributed to the finely dispersed brittle $\omega$ phase in the $\beta$ matrix.

Similar to $\mathrm{Ti}-5 \% \mathrm{Cu}$ and $\mathrm{Ti}-10 \% \mathrm{Cu}$, Ti- $30 \% \mathrm{Nb}$ exhibited a higher degree of hardness and strength, less elongation, and a higher Young's modulus than titanium ${ }^{18)}$. For these similarities, it is no wonder that the grindability of $\mathrm{Ti}-30 \% \mathrm{Nb}$ was better than that of titanium. However, there was a difference in the grindability among these alloys. The grinding rate of the Ti-Cu alloys at low speed was similar to that of titanium ${ }^{32)}$, whereas that of $\mathrm{Ti}-30 \% \mathrm{Nb}$ was significantly higher. The grinding rate of $\mathrm{Ti}-5 \% \mathrm{Cu}$ and $\mathrm{Ti}-10 \% \mathrm{Cu}$ showed a tendency to increase as the grinding speed increased. In contrast, the rate of $\mathrm{Ti}-30 \% \mathrm{Nb}$ decreased. The $\mathrm{Ti}-5 \% \mathrm{Cu}$ at $1500 \mathrm{~m}$. $\min ^{-1}$ and $\mathrm{Ti}-10 \% \mathrm{Cu}$ at $750 \mathrm{~m} \cdot \mathrm{min}^{-1}$ and above exhibited significantly higher grinding ratios than did titanium, but $\mathrm{Ti}-30 \% \mathrm{Nb}$ at any speed did not. The difference in the grindability of the $\mathrm{Ti}-\mathrm{Nb}$ and $\mathrm{Ti}-\mathrm{Cu}$ alloys cannot be explained only from their mechanical properties examined in the present and previous studies ${ }^{18)}$. An explanation for the reduced grindability of $\mathrm{Ti}-30 \% \mathrm{Nb}$ at high speed would be that the properties of this alloy changed with an increase in temperature or deformation speed; however, 
further investigations are needed.

For improved hardness, strength, Young's modulus, and grindability in certain grinding conditions, it would be possible to apply the experimental $\mathrm{Ti}-30 \% \mathrm{Nb}$ alloy to dental machining.

\section{ACKNOWLEDGMENTS}

The authors are extremely grateful to the Sumitomo Sitix Co., Ltd., for providing the high-purity titanium sponge. This study was partially supported by a Grant-inAid for Scientific Research (B) (2) No.12470411 from the Japan Society for the Promotion of Science.

\section{REFERENCES}

1) Ida, K.: Application of titanium in dental field, Quintessence 2(11):114-127, 1983. (in Japanese)

2) Wang, R. R. and Fenton, A.: Titanium for prosthodontic applications: A review of the literature, Quintessence Int $27:$ 401-408, 1996.

3) Nakajima, H. and Okabe, T.: Titanium in dentistry: Development and research in the U.S.A., Dent Mater $J$ 15(2): 77-90, 1996.

4) Okabe, T. and Herø, H.: The use of titanium in dentistry, Cells and Materials $5:$ 211-230, 1995.

5) Jaffee, R. I.: The physical metallurgy of titanium alloys, Chalmers, B. Ed., Progress in metal physics, Vol.7, Pergamon, London, 1958, pp.65-163.

6) Collings, E. W.: Introduction to titanium alloy design, Alloying, Water, J. L., Jackson, M. R., and Sims, C. T. Eds., ASM International, Metals Park, OH, 1988, pp.257-370.

7) ASM committee on titanium and titanium alloys: Properties of titanium and titanium alloys, Metals Handbook 9th Ed., Vol.3 Properties and selection, ASM, Metals Park, OH 1980 , pp.372-406.

8) Andreasen, G.F. and Morrow, R. E.: Laboratory and clinical analyses of nitinol wire, Am J Orthod 73(2): 142-151, 1978.

9) Murakami, H.: Dental application of superplastic forming for titanium complete denture bases, Aichi-Gakuin J Dent Sci 27(1):61-81, 1989. (in Japanese)

10) Ida, K., Togaya, T., Tsutsumi, S. and Takeuchi, M.: Effect of magnesia investments in the dental casting of pure titanium or titanium alloys, Dent Mater $J$ 1(1):8-21, 1982.

11) Okuno, O. and Hamanaka, H.: Application of beta titanium alloys in dentistry, Dentistry in Japan 26 : 101-104, 1989.

12) Okuno, O.: Titanium alloys for prosthetic use, MRS Int Meeting on Advanced Mater, Tokyo, $1: 403-408,1989$.

13) Taira, M., Moser, J.B., and Greener, E. H.: Studies of Ti alloys for dental castings, Dent Mater 5 : 45-50, 1989.

14) Lautenschlager, E. P. and Monaghan, P.: Titanium and titanium alloys as dental materials, Int Dent $J$ 43(3) : 245-253, 1993.

15) Okabe, T., Watanabe, I., Okuno, O. and Takada, Y.: Dental casting of titanium and titanium alloys, Non-Aerospace Applications of Titanium, The Minerals, Metals \& Materials Society, Warrendale, PA, 1998, pp.207-215.

16) Hattori, M., Hasegawa, K., Yoshinari, M., Kawada, E., Oda, Y. and Okabe, T.: Casting accuracy of experimental Ti-Cu alloys, Dent Mater $J$ 20(1) : 16-23, 2001.

17) Takada, Y., Nakajima, H., Okuno, O. and Okabe, T.: Microstructure and corrosion behavior of binary titanium alloys with beta-stabilizing elements, Dent Mater $J$ 20(1) : 34- 
52,2001

18) Takahashi, M., Kikuchi, M., Takada, Y. and Okuno, O.: Mechanical properties and microstructures of dental cast Ti-Ag and Ti-Cu alloys, Dent Mater J 21(3) : 270-280, 2002.

19) Bartlett, E.S.: Properties of pure metals-Niobium (Columbium) (Nb). Metals Handbook 9th Ed. Vol.2, ASM Int, Metals Park, OH, 1972, pp.777-779.

20) Stokinger, H. E.: Niobium, Nb (Columbium, Cb). Patty's Industrial Hygiene and Toxicology 3rd Rev. Ed. Vol.2A Toxicology, Clayton, D. C. and Clayton, F. E. Eds., Wiley, New York, 1981, pp.1841-1853.

21) Shilder, S. and Bilstein, H.: Tantalum and niobium as potential prosthetic materials, Biomaterials 1980. Winter, G.D., Gibbons, D.F. and Plenk, H. Eds., Wiley, New York, 1982 , pp.13-10.

22) Yamamoto, A., Honma, R. and Sumita, M: Cytotoxicity evaluation of 21 metal salts using murine fibroblasts and osteoblastic cells, J Jpn Soc Biomater 14(4) : 167-173, 1995. (in Japanese)

23) Enomoto, S. and Tachikawa, K.: Dental implant materials, Shikazairyo no fukusayo to anzensei, Sato, A. Ed., Gakkenshoin, Tokyo, pp.137-147, 1997. (in Japanese)

24) Matsuno, H., Yokoyama, A., Watari, F., Uo, M. and Kawasaki, T.: Biocompatibility of refractory metals in group IVa and Va evaluated by bioimaging, $J J$ Dent Mater 18(6): 447-462, 1999.

25) Matsuno, H., Yokoyama, A., Watari, F., Uo, M. and Kawasaki, T.: Biocompatibility and osteogenesis of refractory metal implants, titanium, hafnium, niobium, tantalum and rhenium, Biomater 22(11): 1253-1262, 2001

26) Titanium-45Niobium (Corrosion resistant titanium alloy). Alloy Digest, 3-41, Oct 1994.

27) Henson, R.: New titanium-niobium alloy solves autoclave problem, Adv Mater Processes 145(5) : 27-29, 1994.

28) Breme, J. and Wadewitz, V.: Comparison of titanium-tantalum and titanium-niobium alloys for application as dental implants, Int $J$ Oral Maxillofac Implants 4(2): 113-118, 1989.

29) Hildebrand, H. F., Ralison, A., Traisnel, M. and Breme, J.: The electrochemical behavior of TiTa30 and TiNb30 alloys for implantology, Rev Stomatol Chir maxillofac 98 Sup. $1: 56-57,1997$. (in French)

30) Lee, C. M., Ju, C. P. and Chern Lin, J. H.: Structure-property relationship of cast Ti-Nb alloys, J Oral Rehabil 29 : 314-322, 2001.

31) Floquet, I., Ralison, A., Eisenbarth, E., Iost, A., Breme, J. and Hildebrand, H. F.: In vitro biological behavior of a TiNb30 alloy treated with hydroxyapatite and tricalcium phosphate, Rev Stomatol Chir maxillofac 98 Sup. 1:47-49, 1997. (in French)

32) Kikuchi, M., Takahashi, M., Toru, O. and Okuno, O.: Grindability of dental cast Ti-Ag and Ti-Cu alloys, Dent Mater J 22(2) : 191-205 2003.

33) Murray, J. L.: Binary alloy phase diagrams: Nb-Ti, Baker, H. Ed., Alloy phase diagrams, ASM Int, Metals Park, OH, 1987, p.307.

34) Murray, J.L.: The Nb-Ti (niobium-titanium) system, Phase diagrams of binary titanium alloys, ASM Int, Metals Park, OH, 1990, pp.188-194.

35) Moffat, D. L. and Kattner, U.R.: Stable and metastable Ti-Nb phase diagrams, Metal Trans A. 19A : 2389-2397, 1988.

36) Berger, L. W., Williams, D. N. and Jaffee, R. I.: Mechanical Properties and Heat Treatment of Titanium-Niobium Alloys, Trans ASM 50 : 384-397, 1958.

37) Göbel, M., Haanappel, V. A. C. and Stroosnijder, M. F.: On the Determination of diffusion coefficients of oxygen in one-phase $\mathrm{Ti}(\alpha-\mathrm{Ti})$ and two-phase $\mathrm{Ti}-4 \mathrm{Nb}(\alpha-$ and $\beta$ - $\mathrm{Ti})$ by micro-hardness measurements, Oxidation Metals 55(1): 137-151, 2001.

38) Pérez, P., Haanappel, V. A. C. and Stroosnijder, M. F.: The effect of niobium on the oxidation behaviour of titanium in $\mathrm{N}_{2} / 20 \% \mathrm{O}_{2}$ atmospheres, Mater Sci Eng A 284(1-2) : 126$137,2000$.

39) JIS T 5209-1985, Dental carborundum wheels, Japanese Standards Association, Tokyo, 
1985, pp.1-2.

40) Jepson, K.S., Brown, A.R.G. and Gray, J. A.: The effect of cooling rate on the beta transformation in titanium-niobium and titanium-aluminum alloys, The science, technology, and application of titanium: proceedings of an International Conference, Oxford, New York, 1970, pp.677-690.

41) Hanada, S., Ozeki, M. and Izumi, O.: Deformation characteristics in $\beta$ phase Ti-Nb alloys, Metal Trans A, 16A : 789-795, 1985.

42) Brammer, W. G. and Rhodes, C. G.: Determination of omega phase morphology in Ti$35 \% \mathrm{Nb}$ by transmission electron microscopy, Philosophical Mag 16(141): 477-486, 1967.

43) Hickman, B.S.: Omega phase precipitation in alloys of titanium with transition metals, Trans Metal Soc AIME 245 : 1329-1336, 1968.

44) Balcerzak, A.T. and Sass, S. L.: The formation of the $\omega$ phase in Ti-Nb alloys, Metal Trans A 3(6): 1601-1605, 1972.

45) Fedotov, S. G.: Dependence of the elastic properties of titanium alloys on their composition and structure, Kornilov, I. I. Ed., Investigation of titanium alloys, U.S. Dept. of Commerce, Springfield, VA, 1966, pp.199-215.

46) Tabor, D.; A simple theory of static and dynamic hardness, Proc Royal Soc London Ser A A192 : 247-274, 1948.

47) ISO 6871-1:1994, Dental base metal casting alloys-Part 1: Cobalt-based alloys, ISO, Geneva, 1998, pp.1-6.

48) ISO 1562 : 1993, Dental casting gold alloys, ISO, Geneva, 1993, pp.1-5.

49) Bowen, A. W.: Omega phase embrittlement in aged Ti-15\%Mo, Scripta Metallurgica 5 : 709-716, 1971.

50) Takemoto, Y., Hida, M., Sukedai, E. and Sakakibara, A.: Change of deformation mode caused by aging of Ti-14 mass\%Mo alloy single crystals and embrittlement mechanism due to the $\omega$-phase, J Japan Inst Metals 53(10):1004-1012, 1989. (in Japanese)

51) Graft, W.H. and Rostoker, W.: The measurement of elastic modulus of titanium alloys, Symposium on Titanium: presented at the Second Pacific Area National Meeting, ASTM, West Conshohocken, PA, 1957, pp.130-144.

52) Muramatsu, A. et al.: Titanium and its alloys. The modulus of elasticity of metals and alloys, Jpn Soc Mech Eng, Tokyo, 1980, pp.169-176. (in Japanese)

53) Knorr, W. and Scholl, H.: Untersuchungen zum Umwandlungsverhalten von Titan-Molybdän- und Titan-Vanadium-Legierungen, Z Metallkunde 51(10): 605-614, 1960.

54) Chandler, H. E.: Machining of reactive metals. Metals Handbook 9th ed., Vol.16 Machining, ASM Int., Metals Park, OH, 1989, pp.844-846.

55) Shimasaki, K., Ono, K. and Tsuruno, T.: Relation between Brinell hardness of titanium and impurities $\left(\mathrm{O}_{2}, \mathrm{Fe}, \mathrm{N}\right.$ and $\left.\mathrm{C}\right)$, Titanium ' 80 , science and technology, Kimura, H. and Izumi, O. Eds., 1980, pp.1131-1135.

56) Chandler, H. E.: Machining of refractory metals. Metals Handbook 9th ed., Vol.16 Machining, ASM Int., Metals Park, OH, 1989, pp.858-869.

57) Komatsu, S. and Ikeda M.: Thermal conductivity and electrical resistivity of titanium and its alloys, Titanium Japan 46(4): 1-4, 1998. (in Japanese)

58) Takeyama, H. Yoshikawa, T. and Takada, T.: Machinability rating settei ni kansuru kenkyuu, J Jpn Soc Preci Eng 41(4) : 392-394, 1975. (in Japanese)

59) Takeyama, H.: Sessaku gijyutsu no kenkyuu (3), Kikai no Kenkyuu 13(5) : 55-60, 1961. (in Japanese)

60) Araki, T., Yamamoto, S: Nansaku zairyo to hisakusei, Kikai Gijutsu 21(8) : 22-27, 1973. (in Japanese)

61) Nakamura, S.: Free-machining titanium, Sixth World Conference on Titanium, France : 1415-1420, 1988. 